\title{
Whole-body glucose metabolism and mammary energetic nutrient metabolism in lactating dairy cows receiving digestive infusions of casein and propionic acid
}

\author{
S. Lemosquet, ${ }^{*} \dagger^{1}$ G. Raggio, $\ddagger$ G. E. Lobley,§ H. Rulquin, ${ }^{*} \dagger$ J. Guinard-Flament, ${ }^{*} \dagger$ and H. Lapierre\# \\ *INRA, UMR1080 Dairy Production, F-35590 Saint Gilles, France \\ †Agrocampus Ouest, UMR1080 Dairy Production, F-35000 Rennes, France \\ ‡Organic Dairy Research Centre, Guelph University, Alfred campus, 31 rue St-Paul, PO Box 580, Alfred, Ontario K0B 1A0, Canada \\ $\S$ Rowett Institute of Nutrition and Health, University of Aberdeen, Aberdeen AB21 9SB, United Kingdom \\ \#Dairy and Swine Research and Development Centre, Agriculture and Agri-Food Canada, STN Lennoxville, Sherbrooke, Québec J1M 1Z3, \\ Canada
}

\section{ABSTRACT}

This study analyzed the effect of propionate (C3) and casein $(\mathrm{CN})$ on whole-body and mammary metabolism of energetic nutrients. Three multiparous Holstein cows fitted with both duodenal and ruminal cannulas were used in 2 replicated Youden squares with 14-d periods. Effects of CN (743 g/d in the duodenum) and C3 (1,042 $\mathrm{g} / \mathrm{d}$ in the rumen) infusions, either separately or in combination as supplements to a grass silage diet, were tested in a factorial arrangement. The control diet provided $97 \%$ of energy and protein requirements. Within each period, blood samples were taken (d 11) from the carotid artery and the right mammary vein to determine net uptake of energetic nutrients. Plasma blood flow was calculated using the Fick principle (based on Phe and Tyr). On d 13, $\left[6,6-{ }^{2} \mathrm{H}_{2}\right]$ glucose was infused in the jugular vein to determine whole-body glucose rate of appearance ( $\mathrm{Ra}$ ) based on enrichments in arterial plasma. Both C3 and CN treatments increased wholebody Ra (17\% and $13 \%$, respectively) but only $\mathrm{CN}$ increased milk (18\%) and lactose (14\%) yields, suggesting no direct link between whole-body Ra and milk yield. When $\mathrm{CN}$ was infused alone, the apparent ratio of conversion of $\mathrm{CN}$ carbon into glucose carbon was 0.31 but, when allowance was made for the $\mathrm{CN}$ required to support the extra milk protein output, the ratio increased to 0.40 , closer to the theoretical ratio (0.48). This may relate to the observed increases in arterial glucagon concentrations for $\mathrm{CN}$ alone. Conversely, the apparent conversion of infused C3 carbon alone to glucose was low (0.31). With C3, mammary plasma flow increased as did uptakes of lactate, Ala, and Glu whereas the uptake for $\beta$-hydroxybutyrate (BHBA) decreased. Mammary net carbon balance suggested an increase with $\mathrm{C} 3$

Received January 6, 2009

Accepted August 9, 2009.

${ }^{1}$ Corresponding author: Sophie.Lemosquet@rennes.inra.fr treatment in glucose, lactate, Ala, and Glu oxidation within the mammary gland. Mammary glucose uptake did not increase with $\mathrm{CN}$ treatment, despite an increase in glucose arteriovenous difference and extraction rate, because plasma flow decreased $(-17 \%)$. Whereas $\mathrm{CN}$, alone or in combination with $\mathrm{C} 3$, increased both lactose and protein yields, only mammary AA (and BHBA in $\mathrm{CN}$ alone) uptake increased because plasma flow decreased $(-17 \%)$. These data suggest that the observed variations of milk lactose yield (and other milk components) are linked to metabolic interchanges between several energetic nutrients at both the whole-body and mammary levels and are not explained by increases in whole-body glucose availability.

Key words: dairy cow, glucose metabolism, propionic acid, casein

\section{INTRODUCTION}

Milk volume is linked to lactose production via an osmotic pressure mechanism (Linzell and Peaker, 1971). Glucose is the main precursor for lactose. In studies using $\left[\mathrm{U}_{-}{ }^{14} \mathrm{C}\right]$ glucose in vivo, $85 \%$ of lactose carbon secreted by the mammary gland was derived from plasma glucose (Bickerstaffe et al., 1974). Furthermore, most (74\%) of the glucose extracted by the mammary gland is used for lactose synthesis (Hanigan, 1995; Hanigan et al., 2001). Overall, mammary glucose uptake represents 50 to $60 \%$ of whole-body glucose flux (Baldwin et al., 1987b; Lemosquet et al., 2004, 2009). Such observations led to the concept that milk yield would be directly related to whole-body glucose flux (Baldwin et al., 1987a, b; Danfaer, 1994). Therefore, whole-body glucose availability might be a factor limiting milk yield, especially in cows receiving diets based on grass silage in which supplies of glucose or glucose precursors are low (Rigout et al., 2002b). Indeed, increasing doses of glucose by isoenergetic substitutions to a grass silage-based diet 
increased both the whole-body rate of appearance (Ra) of glucose and milk yield (Rigout et al., 2002b).

In the lactating dairy cow, whole-body glucose needs are met primarily from hepatic gluconeogenesis (Danfaer, 1994), although direct intestinal glucose absorption may also contribute for cows fed maize diets (Reynolds, 2006). The major glucose precursor is propionate, produced from rumen fermentation of carbohydrates. Nonetheless, hepatic uptake of propionate does not correlate well with liver glucose release and, indeed, increased propionate supply, via food or ruminal infusions, does not always elicit predicted increments in glucose production (see Kristensen, 2005).

Lactate and AA are also important gluconeogenic precursors (Danfaer, 1994) and the latter may contribute up to $15 \%$ to hepatic glucose synthesis. In addition, AA contribute to kidney gluconeogenesis (Heitmann and Bergman, 1980). Indeed, a recent meta-analysis (Lemosquet et al., 2007) showed that glucose Ra increased linearly with intestinal $\mathrm{CN}$ infusions. Therefore, observed responses in milk output to $\mathrm{CN}$ infusions (Hanigan et al., 1998a) may involve part of the additional AA supply being used to synthesize glucose and thus aid the concomitant secretion of additional milk lactose and protein.

Although CN infusions increase milk yield (Chamberlain and Yeo, 2003), the milk response to propionate (C3) is not always consistent. For example, iso-energetic substitution with C3 increased milk yield in proportion to the amount of glucogenic precursors (C3 plus glucose) absorbed (Rigout et al., 2003), but a positive effect has not always been observed (Hurtaud et al., 1993; Vanhatalo et al., 2003a; Lemosquet et al., 2009). These experiments raised the question of the relationship between lactose synthesis and whole-body glucose availability.

Two studies (Clark et al., 1977; Ranawana and Kellaway, 1977) have examined the effect of postruminal supply of both glucose and $\mathrm{CN}$ on the Ra of glucose and milk yield. There was a trend indicating that treatments enhanced glucose Ra whereas only CN increased or tended to increase milk yield; therefore, the authors suggested that this response was not through increased glucose availability. The dose of glucose infused was, however, relatively low compared with that reported by Rigout et al. (2002b), where both glucose Ra and milk yield increased. One critical point is that lactose synthesis depends not only on whole-body glucose availability but also glucose uptake and utilization within the mammary gland. For example, both decreases and increases in the ratio of lactose output to glucose uptake have been observed with duodenal glucose infusions (Vanhatalo et al., 2003a, b). This leads to the additional question of whether glucose uptake per se is a critical determinant of lactose production or if one of the many nutrients that are used by the mammary gland through complex but interactive pathways can substitute to achieve an appropriate balance of milk constituent output.

In summary, the literature on infusions of additional glucogenic precursors (Clark et al., 1977; Lemosquet et al., 2009) did not show a strong positive relationship between increased $\mathrm{Ra}$ and increased lactose yield. This raises the key question of how additional energy (C3) and protein (casein) regulate milk volume yield and milk constituent output. Is this accomplished through a common mechanism, perhaps via increased whole-body glucose availability? How much of their independent actions overlap, and is there any interaction when supplied together? These questions formed part of the design of the current experiment that compared how C3 and CN supplies, either separately or in combination, modify both whole-body and mammary glucose metabolism and their effect on utilization of other energy-yielding nutrients in relation to milk yield response. Wholebody protein kinetics and mammary AA metabolism from this study have been reported previously (Raggio et al., 2006a, b).

\section{MATERIALS AND METHODS}

\section{Cows, Treatments, and Design}

The complete protocol is detailed in 2 companion papers (Raggio et al., 2006a, b). Briefly, 3 multiparous Holstein cows, averaging $615 \pm 24 \mathrm{~kg}$ of BW and $65 \pm 4$ DIM at the beginning of the study and fitted with both a proximal $\mathrm{T}$-shaped duodenal cannula and a ruminal cannula, were used. Approximately $20 \mathrm{~d}$ after calving, cows were surgically prepared with an ultrasound flow probe (type S, Transonic Systems Inc., Ithaca, NY) implanted around the right external pudic artery and 2 permanent catheters that were placed in the right carotid artery and in the right subcutaneous abdominal vein. The flow probe in 1 cow failed after the second period. The isotope tracer infusions were done via a catheter inserted in the left jugular vein for the duration of the study. The surgical preparations and catheter maintenance were performed as described previously (Guinard et al., 1994). The complete experiment was conducted in accordance with National Legislation on Animal Care (certified by the French Ministry of Agriculture).

The infusion of $\mathrm{CN}$ or C3 was tested, separately or in combination, according to a $2 \times 2$ factorial arrangement: duodenal infusion of calcium caseinate $(\mathrm{CN} ; 743$ $\pm 7 \mathrm{~g} / \mathrm{d}$, estimated to provide $687 \mathrm{~g} / \mathrm{d}$ of protein truly digested in the small intestine and $7.9 \mathrm{MJ} / \mathrm{d}$ of $\mathrm{NE}_{\mathrm{L}}$; Guinard et al., 1994), or ruminal infusion of C3 (1,042 
$\pm 8 \mathrm{~g} / \mathrm{d}$, estimated to provide $15.6 \mathrm{MJ} / \mathrm{d}$ of $\mathrm{NE}_{\mathrm{L}}$; INRA, 1989), or infusion with both CN and C3. Therefore, the 4 treatments were: 1) control, 2) $\mathrm{CN}, 3) \mathrm{C} 3$, and 4) a combination of both $\mathrm{CN}$ and $\mathrm{C} 3(\mathbf{C N}+\mathbf{C 3})$. Each treatment period lasted $14 \mathrm{~d}$.

Diets and preparation of the infusions are detailed in Raggio et al. (2006b). The same basal diet (Raggio et al., 2006b), balanced to provide limited intestinal glucose (Rigout et al., 2003), was fed for the duration of the study. The basal diet was estimated to supply 1,593 $\mathrm{g} / \mathrm{d}$ of protein truly digested in the small intestine and $124 \mathrm{MJ} / \mathrm{d}$ of $\mathrm{NE}_{\mathrm{L}}$ (INRA, 1989), or $1,624 \mathrm{~g} / \mathrm{d}$ of metabolizable protein and $119 \mathrm{MJ} / \mathrm{d}$ of $\mathrm{NE}_{\mathrm{L}}(\mathrm{NRC}, 2001)$. The concentrate was supplied every $3 \mathrm{~h}$ in equal portions from automatic feeders, starting at $0715 \mathrm{~h}$. Grass silage was fed 3 times/d: $25 \%$ at 0715 h, $25 \%$ at 1315 h, and $50 \%$ between $1715 \mathrm{~h}$ and $1915 \mathrm{~h}$. To help maintain a steady metabolic state, the silage was fed 5 times/d during the days involving kinetic measurements: $12.5 \%$ at $0715,1015,1315$, and $1615 \mathrm{~h}$, respectively, and $50 \%$ at $1915 \mathrm{~h}$. Throughout the entire study, access to the diet was limited to $1 \mathrm{~h}$ after each concentrate distribution.

Cows were housed in individual tie stalls and were milked twice daily $(0630 \mathrm{~h}$ and $1830 \mathrm{~h})$. During the second week of each treatment period, the half udders of each cow were milked separately. The mean values of milk samples taken from the right udder at every milking during the second week were used for calculations.

\section{Sampling and Laboratory Analyses}

Milk samples from the right udder were taken at every milking during the second week and were assayed for fat and true protein composition by infrared analysis (MilkoScan, Foss Electric, Hillerød, Denmark). On the morning of d 13, $100 \mathrm{~mL}$ of milk from the right udder was stored for chemical analyses. Lactose was analyzed according to Hurtaud et al. (1993) and metabolites in milk were analyzed according to Rigout et al. (2002a), whereas milk fatty acid (FA) composition were determined as described by Couvreur et al. (2006). Ruminal fluid was collected at 0900, 1200, and $1500 \mathrm{~h}$ on d 12 . The $\mathrm{pH}$ was measured immediately and the remainder of the sample was then filtered through 6 layers of muslin and stored at $-20^{\circ} \mathrm{C}$ before analysis for ammonia and VFA as described by Rigout et al. (2003).

On d 11 of each experimental period, samples were taken from the carotid artery and the mammary vein simultaneously every $2 \mathrm{~h}$ between the morning and evening milking (6 samples/vessel in total) to determine blood gases and the plasma concentrations of glucose, acetate, BHBA, lactate, triglycerides, NEFA, and urea. Blood was collected in 2-mL syringes for blood gases (heparin, S-Monovette, Sarstedt, Nümbrecht, Germany) and in 7.5-mL syringes for other parameters (heparin, S-Monovette, Sarstedt). Blood gases were immediately determined using a blood-gas and mineral analyzer (ABL 625, Radiometer, Copenhagen, Denmark). Blood was centrifuged at 2,000 $\times g$ for 10 min at $4^{\circ} \mathrm{C}$. Plasma was deproteinized with 2 volumes of $0.6 \mathrm{M}$ perchloric acid and filtered for analysis of acetate and lactate. Plasma and deproteinized plasma were stored at $-20^{\circ} \mathrm{C}$ before analysis. Plasma samples for BHBA, NEFA, triglycerides, and deproteinized plasma for acetate and lactate were pooled for each vessel within each cow period just before analyses on a multiparameter analyzer (KONE Instruments Corporation, Espoo, Finland). Enzymatic kits were used for glucose (hexokinase; GLUC HK 07 3672, Roche Diagnostics, Meylan, France), L-lactate (lactate oxidase and peroxidase; Lactate-PAP 61192, Bio-Mérieux S.A., Marcy-l'Etoile, France), NEFA (acetyl-CoA synthase, acyl-CoA oxidase and peroxidase; NEFA C Wako kit, Oxoid S.A., Dardilly, France), and urea (urease and glutamate dehydrogenase; Urée UV Cinétique, KONE Diagnostics, Evry, France). Triglycerides were analyzed using a kit (GPO PAP, Biotrol, Biomerieux, Lyon, France) that included lipase, glycerol kinase, glycerol3 -phosphate oxidase, and peroxidase. This analysis corresponds to the sum of free glycerol and triacylglycerol. Acetate was analyzed using the acetyl-CoA synthase and malate dehydrogenase (Sigma, Saint-Quentin Fallavier, France). The analysis of BHBA was performed with BHBA dehydrogenase (Sigma).

The effect of treatments on glucose Ra was measured on $\mathrm{d} 13$ between $1200 \mathrm{~h}$ and $1630 \mathrm{~h}$. Solutions of $\left[6,6{ }^{2} \mathrm{H}_{2}\right]$ glucose (99 mol\% excess; Cambridge Isotope Laboratories, Andover, MA; $60.0 \pm 0.5 \mathrm{mg} / \mathrm{mL}$ ) were sterilized by passage through a $0.22-\mu \mathrm{m}$ sterile disk filter (Millipore, Saint-Quentin en Yvelines, France). A priming dose $\left(13.2 \pm 0.1 \mathrm{mmol}\right.$ of $\left[6,6{ }^{2} \mathrm{H}_{2}\right]$ glucose $)$ was injected through one jugular vein catheter and the solution was then continuously infused at $24.9 \pm 0.21 \mathrm{mmol} / \mathrm{h}$ for 240 min with a syringe pump (Harvard Apparatus, Les Ulis, France). Arterial blood glucose concentrations were monitored by glucometer (LifeScan One Touch, Johnson \& Johnson Company, Milpitas, CA) every 10 min (from -20-240 min) to ensure steady-state conditions (within $\pm 5 \%$ ). Arterial blood for natural abundance measurement was taken into heparinized syringes (S-Monovette, $7.5 \mathrm{~mL}$, Sarstedt) 180 and $60 \mathrm{~min}$ before the priming dose and further samples were taken at 105, 150,195 , and 240 min of infusion. Blood was centrifuged at $2,500 \times g$ for $10 \mathrm{~min}$ at $4^{\circ} \mathrm{C}$ and the plasma stored at $-20^{\circ} \mathrm{C}$. Plasma glucose isotopic enrichments (IE) were measured by selected ion-monitoring electron-impact gas chromatography-mass spectrometry (5917A, Hewl- 
ett-Packard, Palo Alto, CA) using $50 \mu \mathrm{L}$ of plasma. Glucose was converted in trimethylsilyl-O-methyloxime with methoxyamine hydroxychloride (MOX reagent, Pierce Chemical, Rockford, IL) and N,O-bis (trimethylsilyl) trifluroacetamide with $1 \%$ trimethylchlorosilane (BSTFA $+1 \%$ TMCS; Pierce Chemical). Ion mass-tocharge ratios $(\mathrm{m} / \mathrm{z})$ were monitored at 319 and 321 . The glucose IE (as mole percent excess; MPE) was calculated relative to natural abundance. A reference plasma at $3.31 \pm 0.13 \mathrm{MPE}$ was introduced into each batch of analysis. The intra- and interassay coefficients of variation were 5.0 and $5.2 \%$, respectively.

To determine insulin, glucagon, and IGF-1 levels, 5 arterial blood samples were taken at 0900, 1100, 1300, 1430 , and $1600 \mathrm{~h}$ on d 13 of each period using syringes containing $\mathrm{K}_{2}$-EDTA $(1.2-2 \mathrm{mg} / \mathrm{mL}$; S-Monovette, Sarstedt; $7.5 \mathrm{~mL}$ for insulin and IGF-I determination and $2.5 \mathrm{~mL}$ for glucagon determination). Aprotinin $(260 \mu \mathrm{L} ; 2,600 \mathrm{KIU}$; Antagosan, Hoechst Marion Roussel GmbH, Marbourg, Germany), a protease inhibitor, was added to the syringes used to collect blood for glucagon determination. Blood samples were kept on ice and centrifuged at $2,500 \times g$ for $10 \mathrm{~min}$ at $4^{\circ} \mathrm{C}$. The 3 hormones were analyzed by radioimmunoassay. Insulin and IGF-1 were analyzed as described by Rigout et al. (2002b) and Guinard-Flament et al. (2007), respectively. Glucagon was analyzed using a radioimmunoassay kit (Cliniscience, Linco Research, St. Charles, MI) that involved an antibody specific to pancreatic glucagon and with cross-reactivity to oxyntomodulin, the primary gut glucagon, of $<0.1 \%$. The intraassay coefficient of variation of control plasma was $3.2 \%$ for insulin, $6.5 \%$ for glucagon (all samples were analyzed in a single assay), $3.9 \%$ for IGF-1, and the interassay for IGF-1 was $1.8 \%$.

\section{Calculations}

Mammary Net Uptake of Nutrients. The Fick principle, using Phe and Tyr, was used throughout to estimate mammary plasma flow because the probe was not functional for 1 cow (Raggio et al., 2006a). Plasma net uptake of nutrients was calculated as

$$
\text { plasma net uptake }=([\mathrm{A}]-[\mathrm{V}]) \times \text { plasma flow, }
$$

where $[\mathrm{A}]$ and $[\mathrm{V}]$ are arterial and venous concentration, respectively. To calculated blood net uptake of oxygen $\left(\mathrm{O}_{2}\right)$ and blood net release of carbon dioxide $\left(\mathrm{CO}_{2}\right)$, blood flow was calculated as

$$
\text { blood flow }=\frac{\text { plasma flow }}{(1-\text { hematocrit })}
$$

$\mathrm{O}_{2}$ and $\mathrm{CO}_{2}$ Concentrations. The radiometer ABL 625 analyzer measured $\mathrm{pH}$, partial pressures of $\mathrm{O}_{2}$ and $\mathrm{CO}_{2}$, hemoglobin, and percentage saturation and gave derived values for blood $\mathrm{O}_{2}$ and $\mathrm{CO}_{2}$ concentrations (Siggaard-Andersen et al., 1988) based on maximal saturation of hemoglobin of $1.39 \mathrm{~mL}$ of $\mathrm{O}_{2} / \mathrm{g}$ with a volume of $22.4 \mathrm{~L} / \mathrm{mol}$. The hematocrit derived by ABL 625 calculations, and based on human values, was corrected by -2 points to match the values measured directly by centrifugation in cows and sheep (our unpublished data).

Mammary Gland Extraction Rate and Mammary Clearance of Nutrients. The proportion of mammary arterial flow utilized by the mammary gland on a net basis, mammary gland extraction rate (ER), was calculated using the following equation:

$$
\mathrm{ER}, \%=\frac{([\mathrm{A}]-[\mathrm{V}]) \times \text { plasma flow }}{[\mathrm{A}] \times \text { plasma flow }} \times 100=\frac{([\mathrm{A}]-[\mathrm{V}])}{[\mathrm{A}]} \text {. }
$$

This extraction rate reflects the fraction of arterial supply net removed by transport and metabolism within the gland.

To obtain information on the capacity of mammary net transport system, the mammary clearance rate $(\mathbf{K m})$ of nutrients was calculated using the model of Hanigan et al. (1998b):

$$
\mathrm{Km}, \mathrm{L} / \mathrm{h}=\frac{([\mathrm{A}]-[\mathrm{V}]) \times \text { plasma flow }}{[\mathrm{V}]} .
$$

The Km corresponds to the ability of the udder to clear nutrients from plasma or blood $\left(\mathrm{O}_{2}\right.$ and $\left.\mathrm{CO}_{2}\right)$ per unit of time. This involves the capacity of the transporter system, including the number affinity of transporters, but does have some limitations (Bequette et al., 2000).

Whole-Body Glucose Ra. During the $\left[6,6{ }^{2} \mathrm{H}_{2}\right] \mathrm{glu}-$ cose infusion, plasma glucose concentrations were maintained close to steady state $(\mathrm{CV}=2.81 \% \pm 1.11 \%)$, as were enrichments $(\mathrm{CV}=3.48 \% \pm 1.22 \%)$. The steady state model was then used to calculate whole body glucose $\mathrm{Ra}: \mathrm{Ra}=\mathrm{F} \times\left(\mathrm{IE}_{\text {inf }} / \mathrm{IE}_{\mathrm{p}}-1\right)$, where $\mathrm{F}$ is the $\left[6,6-{ }^{2} \mathrm{H}_{2}\right]$ glucose infusion rate $(\mathrm{mmol} / \mathrm{h}), \mathrm{IE}_{\text {inf }}$ is the IE of the infusate (99 MPE), and $\mathrm{IE}_{\mathrm{p}}$ is the IE of the arterial plasma $\left[6,6-{ }^{2} \mathrm{H}_{2}\right]$ glucose.

Estimated Mammary Carbon Balances. The present mammary carbon net balance used similar principles to those adopted by Waghorn and Baldwin (1984) and by Hanigan and Baldwin (1994). Uptakes included glucose, acetate, BHBA, all AA (Raggio et al., 2006a), and glycerol (from triacylglycerol and free glyc- 
erol), whereas output involved lactose, glycerol required for milk triglycerides, FA synthesized in the mammary gland, and $\mathrm{CO}_{2}$ production. The present estimated carbon balance excluded exogenous long-chain FA uptake and milk output, as suggested by Waghorn (1982) and Waghorn and Baldwin (1984). In contrast to Waghorn and Baldwin (1984), however, exogenous long-chain FA were not considered to be oxidized because no appreciable catabolism was detected during tracer studies in the mammary gland of fed goats (Annison et al., 1967). Fatty acid yields for carbon balance were calculated using fat yield, based on the hypotheses that 1) all, instead of $98 \%$, of the FA in milk are triglycerides (Palmquist et al., 1969) and 2) each triglyceride (TG) has the following composition:

$$
\begin{gathered}
\mathrm{TG}+3 \mathrm{H}_{2} \mathrm{O}=3 \times \mathrm{FA}+\text { glycerol, then } \\
\mathrm{FA}, \mathrm{mol} / 12 \mathrm{~h}=\frac{(\mathrm{FA}, \% \times \text { fat, } \mathrm{g} / 12 \mathrm{~h})}{\mathrm{MW}_{\mathrm{FA}}+\frac{1}{3} \mathrm{MW}_{\text {glycerol }}-\mathrm{MW}_{\mathrm{H}_{2} \mathrm{O}}},
\end{gathered}
$$

where MW is molecular weight. Also, for the estimation of the mammary carbon balance, only FA synthesized within the mammary gland were taken into account. Therefore, it was assumed that all $\mathrm{FA}$ from $\mathrm{C}_{4}$ to $\mathrm{C}_{12}$, $85 \%$ of $\mathrm{C}_{14}$ and $\mathrm{C}_{15}$, and $60 \%$ of $\mathrm{C}_{16}$ and $\mathrm{C}_{17}$ were synthesized in the mammary gland (Palmquist et al., 1969; Waghorn and Baldwin, 1984). The output in milk of AA carbon was calculated as in Hanigan and Baldwin (1994), excluding the fraction of blood protein in milk and taking into account the AA composition of milk protein (Raggio et al., 2006a).

\section{Statistical Analyses}

The original design was a $4 \times 4$ Latin square design, but 1 of the 4 cows did not recover well after surgery. The experiment was then redesigned as 2 incomplete $4 \times 3$ Youden squares with 3 periods each for a total of 17 observations [control $=5$; $\mathrm{C} 3=5 ; \mathrm{CN}=3$ (1 missing value because of a problem with the arterial catheter) or 4 ; $\mathrm{CN}+\mathrm{C} 3=4]$.

Analyses of variance were performed using the MIXED procedure of SAS (SAS Institute, 2004) according to the following statistical model:

$$
\begin{gathered}
\mathrm{y}_{\mathrm{ijk}}=\mu+\operatorname{SQUARE}_{\mathrm{i}}+\operatorname{PERIOD}_{\mathrm{j}}\left(\operatorname{SQUARE}_{\mathrm{i}}\right) \\
+ \text { TREAT }_{\mathrm{k}}+\mathrm{e}_{\mathrm{ijk}},
\end{gathered}
$$

where the effects of the squares (SQUARE), of the periods within the square [PERIOD (SQUARE)], and of the treatments (TREAT) were considered as fixed effects and COW was considered as a random effect. Differences among treatments were compared using orthogonal contrasts, according to the factorial design, estimating the effect of $\mathrm{CN}, \mathrm{C} 3$, and the interaction between the 2 types of infusion $(\mathrm{CN} \times \mathrm{C} 3)$. Results are expressed as least squares means with the largest standard error of mean (SEM). Significance was set at $P \leq 0.05$ and tendency at $0.05<P \leq 0.10$.

\section{RESULTS}

\section{Rumen VFA and Ammonia}

Total VFA concentration in the rumen increased with C3 treatments (Table 1). Absolute concentrations of other VFA were not affected by C3 infusion but their proportions decreased in line with the increase in ruminal propionic acid concentration. This resulted in a decrease in the ratio of acetic acid plus butyric acid to propionic acid. In contrast, $\mathrm{CN}$ treatments tended $(P<$ $0.08)$ to decrease the proportion of propionic acid and to increase isobutyric acid with an overall increase in the ratio of (acetic acid + butyric acid) to C3. The $\mathrm{pH}$ of rumen fluid decreased during C3 treatments. Ammonia concentration exhibited an interaction $(\mathrm{CN} \times \mathrm{C} 3, P$ $=0.02$ ), with an increase when $\mathrm{C} 3$ or $\mathrm{CN}$ were infused alone but a decrease when supplied together.

\section{Milk Production and Composition}

Milk production and composition for the last week of the experimental periods were presented previously (Raggio et al., 2006b). Right udder production from the evening milking during the second week of each treatment matched the variations reported for the whole udder (Table 2; Raggio et al., 2006a). Milk and lactose yields remained unchanged with $\mathrm{C} 3$ treatments but increased with $\mathrm{CN}$ treatments, with no interactions. There was a tendency $(P=0.09)$ for a $\mathrm{CN} \times$ C3 interaction on lactose concentration because this remained unchanged with $\mathrm{C} 3$ treatments but decreased with CN infusion, particularly when CN was infused in combination with C3.

True protein content and yield were both increased with $\mathrm{C} 3$ and CN. Fat concentration and yield tended to decrease with $\mathrm{C} 3$ treatments whereas $\mathrm{CN}$ treatment did not affect fat concentrations but did increase $(P<$ 0.01 ) yield. No interactions were observed between $\mathrm{CN}$ and C3 for any of these parameters. The yield of $\mathrm{C}_{4}$ to $\mathrm{C}_{8}$ FA (Table 3 ) and of $\mathrm{C}_{10}$ to $\mathrm{C}_{14: 1} \mathrm{FA}$ increased $(P \leq$ 0.01 ) during $\mathrm{CN}$ treatments and represented 13.2 and $46.4 \%$, respectively, of the additional FA yield. Infusion of $\mathrm{C} 3$ did not affect these FA. The yield of $\mathrm{C}_{16: 0}$ plus 
Table 1. Effect of CN and propionate (C3) supply on rumen $\mathrm{pH}$ and concentrations of rumen VFA, pH, and ammonia in dairy cows

\begin{tabular}{|c|c|c|c|c|c|c|c|c|}
\hline Item & \multicolumn{4}{|c|}{ Treatment $^{1}$} & SEM & \multicolumn{3}{|c|}{$P$-value ${ }^{2}$} \\
\hline $\begin{array}{l}\text { VFA concentrations, } \mathrm{mol} / \mathrm{L} \\
\text { VFA, mol/100 mol }\end{array}$ & 107.3 & 109.7 & 124.8 & 114.1 & 6.20 & 0.35 & 0.03 & 0.15 \\
\hline Acetic & 66.2 & 67.5 & 57.4 & 59.9 & 1.11 & 0.09 & $<0.001$ & 0.55 \\
\hline Propionic & 18.2 & 15.8 & 28.7 & 25.4 & 1.35 & 0.06 & $<0.001$ & 0.81 \\
\hline Isobutyric & 0.45 & 0.50 & 0.29 & 0.43 & 0.050 & 0.07 & 0.03 & 0.39 \\
\hline Valeric & 1.30 & 1.42 & 1.47 & 1.43 & 0.075 & 0.45 & 0.10 & 0.10 \\
\hline Caproic & 0.81 & 1.03 & 0.46 & 0.63 & 0.136 & 0.04 & 0.002 & 0.72 \\
\hline Ratio $(\mathrm{C} 2+\mathrm{C} 4): \mathrm{C} 3^{3}$ & 4.37 & 4.90 & 2.33 & 2.82 & 0.183 & 0.03 & $<0.001$ & 0.89 \\
\hline $\mathrm{pH}$ & 6.41 & 6.46 & 6.11 & 6.31 & 0.128 & 0.11 & 0.01 & 0.28 \\
\hline $\mathrm{NH}_{3}, \mathrm{mg} / \mathrm{L}$ & 88.0 & 148.4 & 109.3 & 133.5 & 15.5 & $<0.001$ & 0.61 & 0.02 \\
\hline
\end{tabular}

${ }^{1}$ Least squares means presented with the largest SEM, given for $\mathrm{n}=4 ; 18$ observations: control $=5, \mathrm{CN}=4, \mathrm{C} 3=5, \mathrm{CN}+\mathrm{C} 3=4$.

${ }^{2}$ Probability corresponding to the null hypothesis with $\mathrm{CN}, \mathrm{C} 3$, and $\mathrm{CN} \times \mathrm{C} 3$ contrasts.

${ }^{3}$ Ratio (acetic acid + butyric acid):propionic acid.

$\mathrm{C}_{16: 1}$ was not modified by any treatment. The yield of total $\mathrm{C}_{18}$ decreased $(P<0.001)$ with $\mathrm{C} 3$ and this represented $81.8 \%$ of the overall decrease in $\mathrm{FA}$ yield. In contrast, total $\mathrm{C}_{18}$ increased $(P=0.02)$ with $\mathrm{CN}$. The yield of odd-chain FA increased $(+17.7 \% ; P<0.001)$ with $\mathrm{C} 3$ but remained unchanged with $\mathrm{CN}$.

The percentage of individual FA within the fat yield varied within the general groups described above (Table 4). The percentages of most odd-chain FA and of $\mathrm{C}_{12: 0}, \mathrm{C}_{12: 1}, \mathrm{C}_{14: 1}$, and $\mathrm{C}_{16: 1}$ increased with $\mathrm{C} 3$ with a tendency $(P=0.08)$ observed for $\mathrm{C}_{6: 0}$. In contrast, C3 decreased the percentage of $\mathrm{C}_{18: 0} \mathrm{FA}$. Trans- $10 \mathrm{C}_{18: 1}$ and cis-9,trans-11 $\mathrm{C}_{18: 2}$ were not affected by $\mathrm{C} 3$. The ratio of $\mathrm{C}_{14: 1}$ to $\mathrm{C}_{14}$, of $\mathrm{C}_{16: 1}$ to $\mathrm{C}_{16}$, and of cis- $9 \mathrm{C}_{18: 1}$ to $\mathrm{C}_{18: 0}$ were used to estimate desaturase capacity and this was increased by $\mathrm{C} 3$. Casein treatments increased the percentages of even-chain $\mathrm{FA}$ from $\mathrm{C}_{6}$ to $\mathrm{C}_{14: 1}$, whereas the percentage of $\mathrm{C}_{16: 0}$ was reduced. The percentages of $\mathrm{C}_{18: 0}$ and cis-9 $\mathrm{C}_{18: 1}$ were unaffected by $\mathrm{CN}$.

\section{Glucose and Lactate Metabolism}

Arterial plasma concentration of glucose increased $(P$ $<0.001)$ with C3, particularly when in combination with $\mathrm{CN}$ (interaction $\mathrm{CN} \times \mathrm{C} 3, P=0.03$; Table 5). Wholebody glucose Ra increased with both $\mathrm{C} 3(+15.4 \%$; $P<$ $0.01)$ and $\mathrm{CN}(+11.6 \% ; P=0.02)$ treatments but with no interaction. Plasma insulin concentration remained unchanged regardless of treatments. Nonetheless, plasma glucagon concentration increased when $\mathrm{CN}$ was given alone but not when combined with $\mathrm{C} 3(\mathrm{CN} \times \mathrm{C} 3$ interaction; $P=0.04)$. The ratio of insulin to glucagon tended to increase with $\mathrm{C} 3$ treatments. Plasma IGF-1 was not modified by either type of infusion.

During d 12 (Table 6), arterial plasma glucose increased with C3 whereas the arteriovenous (AV) difference tended $(P=0.06)$ to decrease, resulting in a reduced extraction rate $(P=0.03)$ whereas the glucose $\mathrm{Km}$ remained unchanged. The lowered extraction rate was counterbalanced by an increased $(P=0.03)$ blood

Table 2. Effect of CN and propionate (C3) supply on milk yield and composition of the right-half udder in dairy cows ${ }^{1}$

\begin{tabular}{|c|c|c|c|c|c|c|c|c|}
\hline \multirow[b]{2}{*}{ Item } & \multicolumn{4}{|c|}{ Treatment $^{2}$} & \multirow[b]{2}{*}{ SEM } & \multicolumn{3}{|c|}{$P$-value ${ }^{3}$} \\
\hline & Control & $\mathrm{CN}$ & $\mathrm{C} 3$ & $\mathrm{CN}+\mathrm{C} 3$ & & $\mathrm{CN}$ & C3 & $\mathrm{CN} \times \mathrm{C} 3$ \\
\hline Milk, kg/12 h & 6.37 & 7.44 & 6.42 & 7.62 & 0.472 & $<0.001$ & 0.48 & 0.68 \\
\hline True protein, $\mathrm{g} / \mathrm{kg}$ & 29.5 & 30.6 & 30.9 & 33.0 & 1.71 & 0.01 & 0.006 & 0.32 \\
\hline True protein, g/12 h & 188 & 226 & 196 & 249 & 5.1 & $<0.01$ & 0.02 & 0.18 \\
\hline Fat, $\mathrm{g} / \mathrm{kg}$ & 44.8 & 45.1 & 43.3 & 40.2 & 3.33 & 0.45 & 0.08 & 0.32 \\
\hline Fat, $\mathrm{g} / 12 \mathrm{~h}$ & 283 & 333 & 274 & 304 & 9.1 & 0.002 & 0.07 & 0.28 \\
\hline Lactose, ${ }^{4} \mathrm{~g} / \mathrm{kg}$ & 50.0 & 48.6 & 50.1 & 47.9 & 0.53 & $<0.001$ & 0.26 & 0.09 \\
\hline Lactose, ${ }^{4} \mathrm{~g} / 12 \mathrm{~h}$ & 319 & 362 & 322 & 366 & 25.1 & $<0.001$ & 0.64 & 0.98 \\
\hline
\end{tabular}

${ }^{1}$ Measured in the evening milkings of the second week of each period.

${ }^{2}$ Least squares means presented with the largest SEM, given for $\mathrm{n}=4 ; 18$ observations: control $=5, \mathrm{CN}=4, \mathrm{C} 3=5, \mathrm{CN}+\mathrm{C} 3=4$.

${ }^{3}$ Probability corresponding to the null hypothesis with $\mathrm{CN}, \mathrm{C} 3$, and $\mathrm{CN} \times \mathrm{C} 3$ contrasts.

${ }^{4}$ Analyzed as monohydrated lactose (molecular weight $=360.3 \mathrm{~g} / \mathrm{mol}$ ). 
Table 3. Effect of CN and propionate (C3) supply on milk fatty acid yield measured on the right-udder in dairy cows

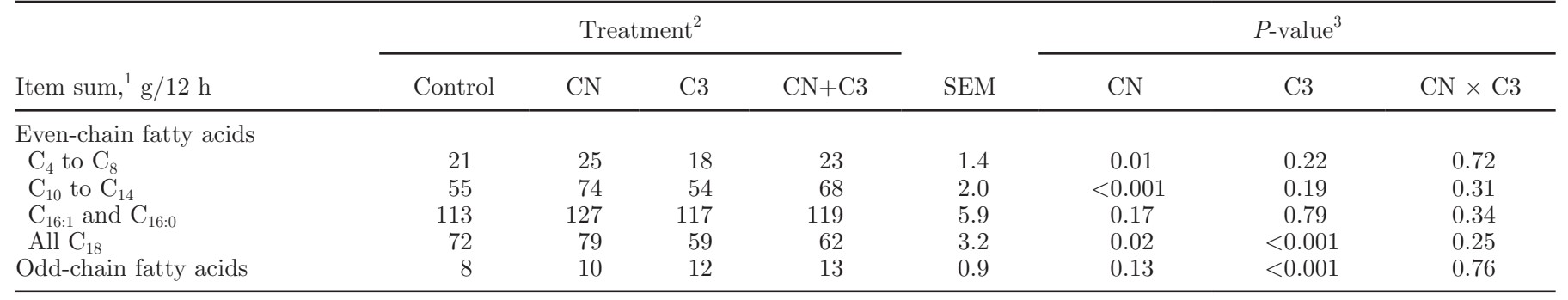

${ }^{1}$ Calculated using the fatty acid percentage measured on the morning of $\mathrm{d} 13$ for each period and the average milk fat yield measured in the evening milkings of the second week of each period.

${ }^{2}$ Least squares means presented with the largest SEM, given for $\mathrm{n}=4 ; 18$ observations: control $=5, \mathrm{CN}=4, \mathrm{C} 3=5, \mathrm{CN}+\mathrm{C} 3=4$.

${ }^{3}$ Probability corresponding to the null hypothesis with $\mathrm{CN}, \mathrm{C} 3$, and $\mathrm{CN} \times \mathrm{C} 3$ contrasts.

Table 4. Effect of CN and propionate (C3) supply on milk fatty acid percentage ${ }^{1}$

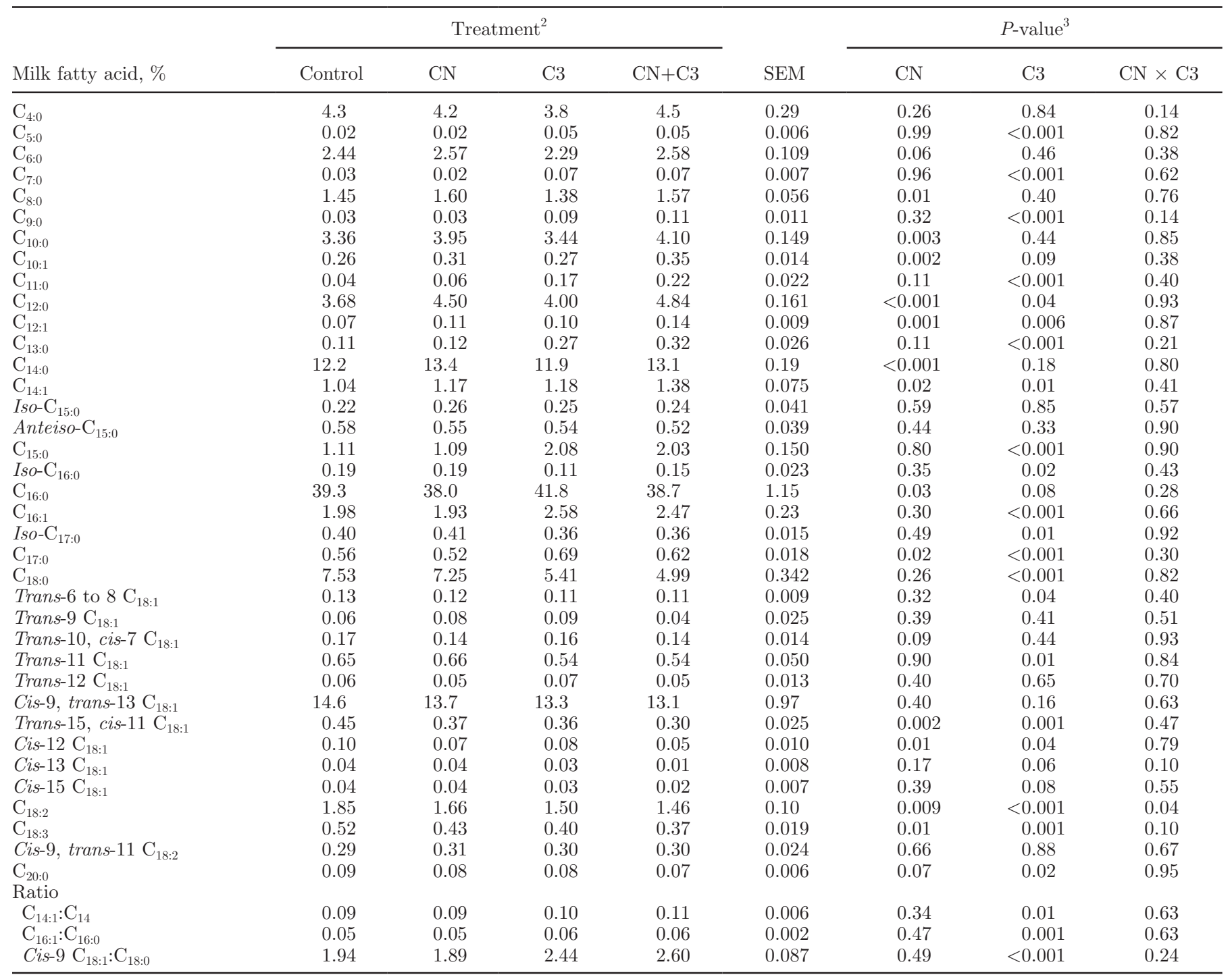

${ }^{1}$ Measured on the morning of d 13 for each period.

${ }^{2}$ Least squares means presented with the largest SEM, given for $\mathrm{n}=4 ; 18$ observations: control $=5, \mathrm{CN}=4, \mathrm{C} 3=5, \mathrm{CN}+\mathrm{C} 3=4$.

${ }^{3}$ Probability corresponding to the null hypothesis with $\mathrm{CN}, \mathrm{C} 3$, and $\mathrm{CN} \times \mathrm{C} 3$ contrasts. 
Table 5. Effect of CN and propionate (C3) supply on glucose metabolism in dairy cows

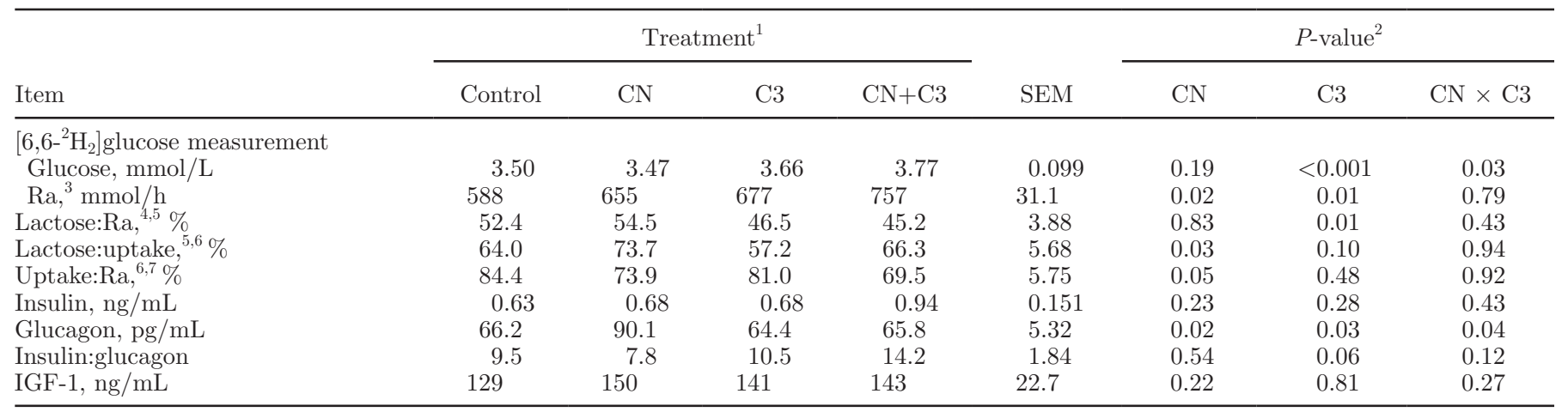

${ }^{1}$ Least squares means presented with the largest SEM, given for $\mathrm{n}=3 ; 17$ observations: control $=5, \mathrm{CN}=3, \mathrm{C} 3=5, \mathrm{CN}+\mathrm{C} 3=4$.

${ }^{2}$ Probability corresponding to the null hypothesis with $\mathrm{CN}, \mathrm{C} 3$, and $\mathrm{CN} \times \mathrm{C} 3$ contrasts.

${ }^{3}$ Whole-body glucose rate of appearance (Ra) measured on d 13.

${ }^{4}$ Mean of lactose yield produced by the whole udder during the evening milkings during the second week of each period and right mammary gland uptake measured on d 12 of each period.

${ }^{5}$ The ratio was calculated on a carbon basis.

${ }^{6}$ Mean of lactose yield produced by the right udder for the evening milkings during the second week of each period.

${ }^{7}$ Calculated using lactose/uptake and uptake/Ra.

flow, with the result that net glucose uptake was not affected by $\mathrm{C} 3$ treatment. Arterial plasma glucose remained unchanged with $\mathrm{CN}$ treatment, whereas both glucose AV difference $(P=0.03)$ and extraction rates $(P=0.05)$ increased; glucose $\mathrm{Km}$ was not modified. Nonetheless, because mammary plasma flow decreased $(P=0.04)$ with $\mathrm{CN}$, this led to no change in glucose uptake.

The ratio of milk lactose yield to Ra decreased $(P=$ 0.01) with C3 but was not affected with CN (Table 5). The ratio of lactose yield to mammary glucose uptake tended to decrease $(P=0.10)$ with $\mathrm{C} 3$ but increased $(P=0.03)$ with $\mathrm{CN}$. The ratio of mammary glucose uptake to whole-body glucose Ra decreased $(P=0.05)$ with $\mathrm{CN}$ treatment.

Arterial concentration of plasma lactate (Table 6) remained unchanged with $\mathrm{C} 3$ and $\mathrm{CN}$ treatments but the AV difference, extraction rate, $\mathrm{Km}$, and net uptake all increased $(P<0.01)$ with $\mathrm{C} 3$.

\section{Fat Precursor Metabolism, $\mathrm{O}_{2}$ Consumption, and $\mathrm{CO}_{2}$ Production}

Arterial concentrations of acetate, BHBA, NEFA, and triglycerides decreased $(P<0.01)$ with $\mathrm{C} 3$ treatment, as did the AV differences of acetate, BHBA, and triglycerides. In addition, the extraction rates of triglycerides tended $(P=0.07)$ to decrease with $\mathrm{C} 3$ but triglycerides $\mathrm{Km}$ did not change. The acetate $\mathrm{Km}$ increased $(P<0.01)$ with $\mathrm{C} 3$ treatment. Uptake of BHBA decreased $(P<0.04)$ and release of NEFA across the mammary gland tended $(P=0.06)$ to increase with $\mathrm{C} 3$, whereas extraction rate tended $(P=$
$0.07)$ to be more negative and $\mathrm{Km}(P=0.03)$ was more negative in $\mathrm{C} 3$ treatments. In contrast, $\mathrm{CN}$ treatments did not change arterial plasma concentrations nor AV differences of fat precursors, except for BHBA (Table $6)$. Arterial concentration of BHBA tended $(P=0.08)$ to increase during $\mathrm{CN}$ treatments and there were $\mathrm{CN}$ $\times$ C3 interactions for AV difference $(P<0.01)$ and net uptake $(P=0.06)$ of BHBA, in that both increased when $\mathrm{CN}$ was infused alone but not in the presence of C3. Net uptake of acetate also tended $(P=0.09)$ to increase with $\mathrm{CN}$ treatments.

Arterial concentrations of blood $\mathrm{O}_{2}$ and $\mathrm{CO}_{2}$ were not affected by $\mathrm{C} 3$ or $\mathrm{CN}$ treatments. However, blood $\mathrm{O}_{2} \mathrm{AV}$ differences decreased $(P<0.01)$ with $\mathrm{C} 3$ and increased $(P=0.03)$ with $\mathrm{CN}$. Blood $\mathrm{CO}_{2} \mathrm{AV}$ differences became less negative $(P=0.01)$ with $\mathrm{C} 3$ but more negative $(P$ $=0.02$ ) with $\mathrm{CN}$, although to a lesser extent when $\mathrm{CN}$ was infused with $\mathrm{C} 3(\mathrm{CN} \times \mathrm{C} 3$ interaction; $P=0.04)$. Net uptake of blood $\mathrm{O}_{2}$ and net release of blood $\mathrm{CO}_{2}$ did not change with treatments. The changes in $\mathrm{AV}$ differences of $\mathrm{CO}_{2}$ and $\mathrm{O}_{2}$ led to a $\mathrm{CN} \times \mathrm{C} 3$ interaction $(P=0.04)$ for the respiratory quotient that increased when C3 was given alone but decreased when C3 and $\mathrm{CN}$ were supplied together.

\section{Milk Metabolites}

Milk concentrations (Table 7) of glucose-6-P and glycerol-3-P increased $(P<0.01)$ during C3 treatments, whereas malate was reduced $(P=0.01)$. The ratio of 2-oxoglutarate to isocitrate, a reflection of the activity of a major pathway for production of NADPH, was not affected by treatments. Casein treatments 
Table 6. Effect of $\mathrm{CN}$ and propionate (C3) supply on right mammary gland energetic precursors ${ }^{1}$

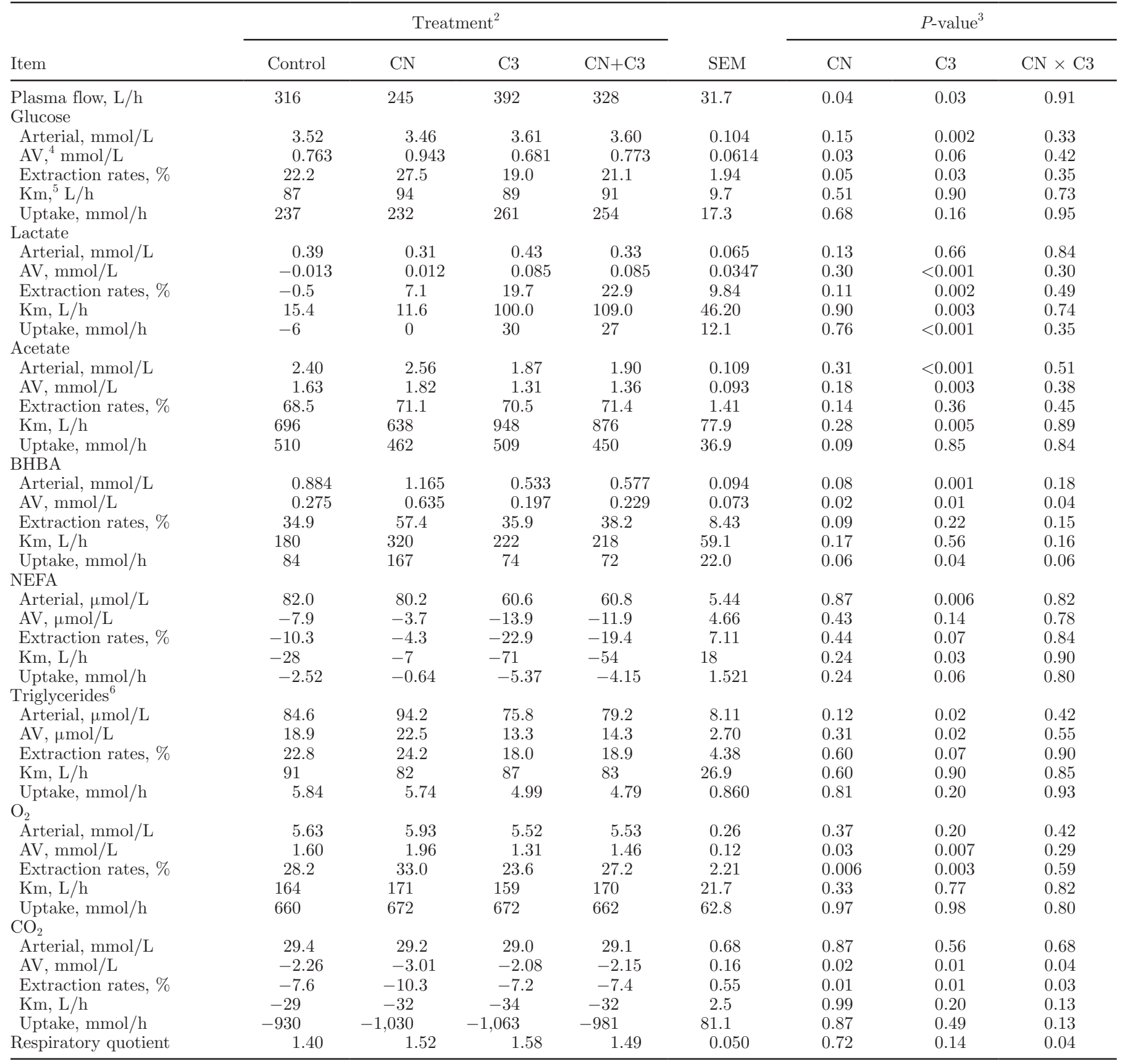

${ }^{1}$ Measured on d 12 of each period.

${ }^{2}$ Least squares means presented with the largest SEM, given for $\mathrm{n}=3 ; 17$ observations: control $=5, \mathrm{CN}=3, \mathrm{C} 3=5, \mathrm{CN}+\mathrm{C} 3=4$.

${ }^{3}$ Probability corresponding to the null hypothesis with $\mathrm{CN}$, C3, and $\mathrm{CN} \times \mathrm{C} 3$ contrasts.

${ }^{4}$ Arteriovenous difference.

${ }^{5}$ Clearance rate; calculated using Hanigan et al. (1998b).

${ }^{6}$ Triacylglycerol plus free glycerol were analyzed enzymatically. 
Table 7. Effect of CN and propionate (C3) supply of mammary gland on milk $\mathrm{N}$ composition and milk metabolites ${ }^{1}$

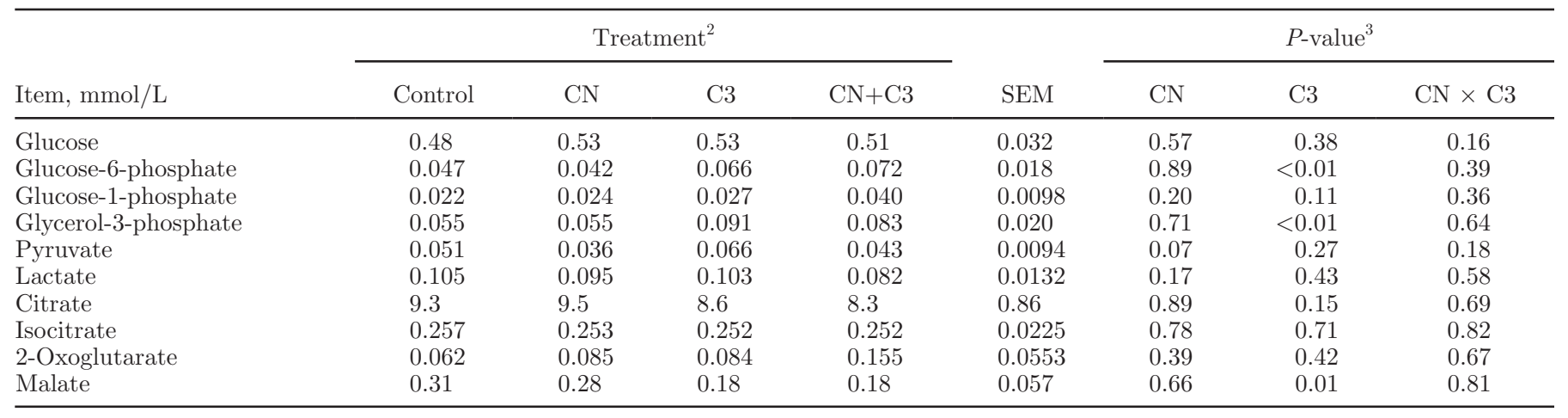

${ }^{1}$ Measured on the morning of d 13 for each period.

${ }^{2}$ Least squares means presented with the largest SEM, given for $\mathrm{n}=4 ; 18$ observations: control $=5, \mathrm{CN}=4, \mathrm{C} 3=5, \mathrm{CN}+\mathrm{C} 3=4$.

${ }^{3}$ Probability corresponding to the null hypothesis with $\mathrm{CN}, \mathrm{C} 3$, and $\mathrm{CN} \times \mathrm{C} 3$ contrast.

tended $(P=0.07)$ to decrease pyruvate concentrations in milk.

\section{DISCUSSION}

\section{Milk Yield and Whole-Body Ra of Glucose}

Milk Yield Increased Only in Response to CN. In agreement with many previous reports, $\mathrm{CN}$ treatment improved milk yield (Chamberlain and Yeo, 2003; Lemosquet et al., 2007) although there was a smaller proportional increase in lactose output, linked to a lower lactose concentration, as has been observed in other studies (Lemosquet et al., 2007). Reported effects of C3 infusion on milk volume output show inconsistent responses with no (Hurtaud et al., 1993; Lemosquet et al., 2009) to moderate increases (Rigout et al., 2003). These inconsistent responses may be affected by whether the C3 is provided as a supplement to the diet (present experiment; Lemosquet et al., 2009) or as an iso-energetic substitution because, in a meta-analysis, C3 infusion increased milk yield compared with isoenergetic control (Rigout et al., 2003).

Whole-Body Ra of Glucose Increased with C3 and $\boldsymbol{C N}$. Despite the differences in milk output responses, both $\mathrm{C} 3$ and $\mathrm{CN}$ increased glucose $\mathrm{Ra}$ separately. The net increases in glucose carbon averaged 0.31 of the carbon infused for both $\mathrm{C} 3$ and $\mathrm{CN}$ alone. In earlier studies (Lemosquet et al., 2004, 2009; see Kristensen, 2005 for a review), based on ruminal C3 supplementation, the conversions of propionate to glucose were only 30 to $40 \%$ of that expected theoretically. In the present experiment, the whole-body $\mathrm{CO}_{2}$ entry rate was increased when $\mathrm{C} 3$ was supplemented (Raggio et al., 2006b). This suggests increased nutrient oxidation, either of C3 directly as observed in steers (Veenhuizen et al., 1988), or of other metabolites whose gluconeogenic role may be replaced by C3. In either case, the apparent efficiency of conversion of C3 to glucose would be less than theoretical.

If all of the AA infused as CN were used in gluconeogenesis (Van Milgen, 2002), the increment of Ra would maximally represent 0.48 of the carbon infused as $\mathrm{CN}$. In $\mathrm{CN}$ treatment, the apparent conversion efficiency of the infused CN carbon to glucose carbon (based on the increment in glucose $\mathrm{Ra}$ ) was only 0.31 , but when allowance was made for the $\mathrm{CN}$ required to support the extra milk protein output then the ratio increased to 0.40. Close matches between observed and theoretical values have been reported previously (Clark et al., 1977; König et al., 1984; see Lemosquet et al., 2007 for meta-analysis).

Besides the additional gluconeogenic precursors provided by the $\mathrm{CN}$ infusions, other mechanisms may also operate to affect Ra. For example, CN alone increased glucagon concentration. Glucagon may act to limit the action of insulin on inhibition of hepatic gluconeogenesis. In addition, glucagon stimulates glycogenolysis, another source of plasma glucose. Glucagon also increases the rate of protein breakdown and the uptake of $\mathrm{AA}$ by the liver, providing further gluconeogenic precursors (Danfaer, 1994). Unfortunately, the current data do not allow these various mechanisms to be separated. Furthermore, the changes in glucose Ra need to be interpreted carefully because these involve a composite of gluconeogenesis, glycogenolysis, and glucose absorption, although the latter is probably minor in the present experiment. Increases of plasma glucagon and glycogen turnover were observed in muscle and the hearts and livers of rats fed CN (Gannon and Nuttal, 1988, 1995). Indeed, changes in Ra need not necessarily represent altered net supply of glucose because increased glycogen turnover, through concurrent elevation of glycogenolysis and glycogen synthesis, would increase glucose Ra but not provide additional glucose for lactose synthesis. When C3 was infused with CN, the increase in plasma 
glucagon was suppressed (interaction at $P=0.04$ ) and this may limit the involvement of some of the mechanisms described above in either altered glucose supply or Ra when additional protein and energy are supplied together.

No Direct Link Between Increased Ra of Glucose and Lactose Yield. In the present experiment, the Ra of glucose was increased by either the $\mathrm{C} 3$ or $\mathrm{CN}$ infusions and yet only the latter increased milk yield and lactose output. Therefore, glucose availability, as assessed by glucose Ra, does not seem to be the driving mechanism (or "push") to increase lactose synthesis. Similarly, increments in glucose $\mathrm{Ra}$ in response to other gluconeogenic sources, such as NEAA $(1,440 \mathrm{~g} / \mathrm{d})$ and $\mathrm{C} 3$, or directly to glucose infusions also failed to elicit an increased milk yield (Lemosquet et al., 2009).

\section{Lactose Synthesis Not Linked to Mammary Glucose Uptake}

In the present experiment, mammary glucose uptake was not increased with either $\mathrm{C} 3$ or $\mathrm{CN}$ treatments, but the latter resulted in greater lactose yield whereas the former did not. The C3 treatment led to increased $(+28.3 \%)$ mammary plasma flow and decreased $(-14.8 \%)$ glucose AV difference, such that net glucose uptake was not altered significantly. Such opposing changes in mammary plasma flow and AV difference have been reported previously in response to increases in either glucose supply (Rigout et al., 2002b; Vanhatalo et al., 2003b) or feed intake (Guinard-Flament et al., 2007). Increased feed intake (particularly energy supply) is accompanied by elevated cardiac output and heart rate (Guinard-Flament et al., 2007) and this leads to increased portal blood flow (Wieghart et al., 1986). Therefore, because total energy intake was increased by the current treatment (basal diet plus C3 infusions), this may lead to greater systemic blood flows, including at the mammary gland. The fact that mammary uptake did not increase whereas mammary arterial plasma supply increased (decreased extraction rate) suggests that glucose uptake is regulated, in part, by factors within the mammary gland (Madsen et al., 1999).

With CN treatments, the unchanged glucose uptake was a consequence of decreased $(-19 \%)$ mammary plasma flow and increased $(+19 \%)$ glucose AV, with both parameters altering in the opposite direction to the findings with C3. This finding was somewhat surprising because previous studies in this laboratory had not shown any decrease in mammary plasma flow, measured either with an ultrasonic flow probe (Guinard et al., 1994) or by the Fick principle (Raggio et al., 2004), in response to increased protein supply. Furthermore, no relationship was found between protein intake and mammary plasma flow based on a meta-analysis of the available literature (Lemosquet et al., 2007). In the current study, plasma flow was estimated by the Fick method using Phe and Tyr as AA markers as in Raggio et al. (2004), but almost identical estimates were obtained when comparisons were based on Met (Raggio et al., 2006a), as has been observed in other studies (Rulquin et al., 2007). While a systematic underestimate of blood flow may occur through mammary gland uptake of peptides, such concerns usually exist only with low protein supply (Bequette et al., 1999). Indeed, any such error in the current study is probably relatively small based on the observations that mammary $\mathrm{N}$ balance was not different from zero in either the control or CN treatments (Raggio et al., 2006a); this is supported by corresponding agreements for the carbon balance reported here (see below). Furthermore, the mammary gland does exhibit considerable flexibility in response to AA supply. For example, when His supply to support mammary metabolism was increased from deficient to adequate, this increase was accompanied by reduced blood flow and altered transport kinetics for His (Bequette et al., 2000). Indeed, increased arterial concentrations for many of the essential AA, including His, resulted from the CN supplementation (Raggio et al., 2006b) and this improved availability may have led to the decreased plasma flow observed in the current study.

\section{Regulation Through Intramammary Metabolism}

In line with the lack of change in net glucose uptake in response to $\mathrm{C} 3$ and $\mathrm{CN}$ treatments, there were no differences observed in glucose $\mathrm{Km}$. This suggests that the capacity of the glucose transport systems was not affected, in agreement with Xiao and Cant (2005) who proposed that intramammary events, such as phosphorylation of the glucose, were important control steps. The trend of a decreased ratio of lactose yield relative to glucose uptake with C3 treatments suggests that mammary glucose was used for metabolic purposes other than lactose synthesis with C3. With CN treatments, despite no change in net glucose uptake, there was increased lactose production so that the utilization of intramammary glucose differed from C3. This also meant that, for $\mathrm{CN}$, some of the outcomes of mammary glucose metabolism during the control and C3 treatments will need to be substituted by other substrates and this can be explored through consideration of the various metabolites that contribute to the carbon balance monitored in the present experiment.

Within the mammary gland, glucose is necessary to support activities related to the extra milk synthesis, including lactose and glycerol synthesis, carbon for 
Table 8. Effect of $\mathrm{CN}$ and propionate (C3) supply on half-udder carbon balances in dairy cows ${ }^{1}$

\begin{tabular}{|c|c|c|c|c|c|c|c|c|}
\hline Carbon, mmol/h & \multicolumn{4}{|c|}{ Treatment $^{2}$} & SEM & \multicolumn{3}{|c|}{$P$-value ${ }^{3}$} \\
\hline Uptake $^{4}$ & 3,420 & 3,747 & 3,681 & 3,606 & 207.0 & 0.47 & 0.76 & 0.29 \\
\hline $\mathrm{AA}$ & 622 & 732 & 679 & 814 & 38.2 & $<0.01$ & 0.06 & 0.66 \\
\hline Ala & 27 & 11 & 39 & 32 & 2.1 & $<0.001$ & $<0.001$ & 0.02 \\
\hline Glu & 59 & 44 & 77 & 63 & 6.5 & 0.03 & 0.02 & 0.94 \\
\hline Output $^{5}$ & 3,264 & 3,802 & 3,440 & 3,776 & 114.4 & $<0.001$ & 0.33 & 0.17 \\
\hline Lactose & 892 & 1,025 & 894 & 1,008 & 33.3 & $<0.001$ & 0.70 & 0.58 \\
\hline FA synthesized $^{5}$ & 715 & 855 & 738 & 840 & 37.7 & $<0.01$ & 0.90 & 0.57 \\
\hline Glycerol $^{5}$ & 98 & 115 & 96 & 108 & 4.2 & 0.01 & 0.28 & 0.60 \\
\hline $\mathrm{AA}$ & 641 & 783 & 663 & 836 & 19.9 & $<0.001$ & 0.07 & 0.36 \\
\hline Ala & 18 & 21 & 19 & 22 & 0.5 & $<0.001$ & 0.09 & 0.75 \\
\hline Ala & 9 & -10 & 20 & 10 & 1.8 & $<0.001$ & $<0.001$ & 0.02 \\
\hline Glu & -5 & -33 & 9 & -20 & 6.9 & $<0.001$ & 0.06 & 0.93 \\
\hline$(\mathrm{BHBA}+$ acetate $)-\mathrm{FA}^{7}$ & 656 & 746 & 589 & 333 & 136.4 & 0.47 & 0.09 & 0.17 \\
\hline
\end{tabular}

${ }^{1}$ Calculated from measurement made on d 12 of each period.

${ }^{2}$ Least squares means presented with the largest SEM, given for $\mathrm{n}=3 ; 17$ observations: control $=5, \mathrm{CN}=3, \mathrm{C} 3=5, \mathrm{CN}+\mathrm{C} 3=4$.

${ }^{3}$ Probability corresponding to the null hypothesis with $\mathrm{CN}, \mathrm{C} 3$, and $\mathrm{CN} \times \mathrm{C} 3$ contrasts.

${ }^{4}$ Sum of carbon from glucose, lactate, glycerol from free glycerol plus glycerol liberated from triacylglycerol, acetate, BHBA, and all AA uptakes.

${ }^{5} \mathrm{Sum}$ of carbon from blood $\mathrm{CO}_{2}$ plus milk lactose plus milk protein plus milk glycerol of triglycerides and milk fatty acids (FA) synthesized within the mammary gland $\left[\left(\mathrm{C}_{4}\right.\right.$ to $\left.\left.\mathrm{C}_{13}\right) \times 1+\left(\mathrm{C}_{14}+\mathrm{C}_{15}\right) \times 0.85+\left(\mathrm{C}_{16}+\mathrm{C}_{17}\right) \times 0.60\right]$.

${ }^{6}$ Carbon from glucose uptake minus lactose and glycerol of milk triglycerides.

${ }^{7}$ Carbon from BHBA plus acetate uptakes - fatty acids synthesized.

NEAA synthesis, and NADPH and ATP requirements for triglyceride and protein synthesis (Smith et al., 1983). If more (or less with C3) glucose is diverted to lactose synthesis, the metabolism of other metabolites must increase (or decrease) in compensation. This forms the basis of the partial carbon balance $(\mathrm{mmol} / \mathrm{h}$; Table 8$)$ performed. Based on the hypotheses and assumptions detailed in the Materials and Methods section, mammary net carbon balances were not significantly different from zero (range $=-119$ to $+112 \mathrm{mmol}$ of $\mathrm{C} / \mathrm{h}$ ) and, indeed, output accounted for 98.6 to $107.0 \%$ of uptake. While such accounting suggests that the major contributors to carbon exchanges across the mammary gland have been included, no allowance was included for any variation in the contribution of exogenous FA to the proportion of milk C16 FA. In addition, these FA were not considered to be oxidized within the mammary gland.

Effect of C3 Treatments on Nutrient Oxidation. Alterations in the net utilization of several nutrients observed with C3 treatments suggested changes in their catabolism and oxidation. For example, glucose plus lactate and AA uptake, notably Ala and Glu, increased (in total by $302 \mathrm{mmol}$ of $\mathrm{C} / \mathrm{h}$ ) whereas BHBA uptake decreased $(-209 \mathrm{mmol}$ of $\mathrm{C} / \mathrm{h})$. Despite these changes, the amount of carbon output in milk was not altered by $\mathrm{C} 3$ treatment and, therefore, metabolite utilization and catabolism including oxidation must have altered within the mammary gland to maintain the overall balance. For example, the carbon balance between glucose minus lactose and glycerol synthesis for milk triglycerides tended to increase $(+164 \mathrm{mmol}$ of $\mathrm{C} / \mathrm{h})$ with $\mathrm{C} 3$, suggesting an increase in glucose oxidation (Table 8). In addition, the carbon balance between BHBA plus acetate uptake minus FA synthesized within the mammary gland tended to decrease $(-240 \mathrm{mmol}$ of $\mathrm{C} / \mathrm{h})$ with C3, suggesting lowered acetate oxidation. Similarly, increased Ala and Glu uptake (17 and $19 \mathrm{mmol}$ of $\mathrm{C} / \mathrm{h}$, respectively) accounted for half of the additional carbon uptake from AA $(70 \mathrm{mmol}$ of $\mathrm{C} / \mathrm{h})$; this extra must have been utilized in pathways other than protein synthesis, based on positive net balances $(+15.5$ and $+12.5 \mathrm{mmol}$ of $\mathrm{C} / \mathrm{h}$ for Ala and Glu, respectively).

Ruminal C3 treatment decreased long-chain FA concentration in milk and, consequently, milk fat yield, as already observed (Hurtaud et al., 1998), but this 
was more pronounced than if $\mathrm{C} 3$ was provided as an energy substitute (Rigout et al., 2003). This is probably related to altered supply of long-chain FA because these are not synthesized within the mammary gland but instead are derived from plasma triglycerides. Arterial concentrations of triglycerides, NEFA, BHBA, and acetate decreased with C3 treatment, which suggests lowered whole-body availability of fat precursors. Indeed, across the mammary gland, uptake of BHBA was reduced whereas net release of NEFA increased. Similar arterial and mammary responses, leading to lowered long-chain FA yield in milk, have been observed during duodenal glucose infusions (Rigout et al., 2002a).

Intramammary Regulation of Lactose Synthesis with $C N$. Simple consideration of the carbon balance on the $\mathrm{CN}$ treatment clearly shows a degree of metabolic switching, and to a greater degree than observed for C3. In addition to the increased ratio of lactose output to glucose uptake (Table 5), there was a tendency for reduced net balance (Table 8) between glucose uptake and the combined outputs of lactose and glycerol (in triglycerides). This reflects that more glucose was diverted to anabolic products (notably lactose) with less to support other processes, such as energy supply. These latter roles are then substituted, in part, by extra BHBA uptake, observed for CN alone; however, it cannot be resolved whether the diversion of more glucose to lactose stimulates greater BHBA removal or whether uptake of the latter spares glucose oxidation and releases more carbon for anabolic fates. The only direct measure of altered oxidation in the current study involved Leu, which increased 2-fold in CN treatments (Raggio et al., 2006a). This would provide acetyl-CoA for energetic purposes and to support milk fat synthesis. There were also positive net carbon balances for the other branched-chain AA (Raggio et al., 2006a) and if these, and other AA, had also increased oxidation then this would provide 3-carbon intermediates that could substitute for glucose in a variety of metabolic pathways (Bequette et al., 2006). Indeed, tracer studies in vitro with mammary gland explants from goats (Roets et al., 1983; Bequette et al., 2006) have shown incorporation of AA-carbon into lactose (most essential AA) and milk fat (Leu). Care is needed, however, in the interpretation of kinetic fluxes between nutrients with isotope studies sharing common pathways because part of the transfer of an isotope may just be the result of a reciprocal exchange between 2 metabolites rather than a net gain in one direction.

Interactions Between $\mathrm{CN}$ and C3 Could Be Linked to Oxidative Process The C3 and CN treatments separately demonstrated the different influences on milk production and the metabolic adaptability of the mammary gland to respond to varied nutrient supplies. The important question is, "Do these energy and protein supplies act in a competitive or additive manner when given in combination?" In the present experiment only a few interactions were statistically significant: rumen $\mathrm{NH}_{3}$ concentrations, whole-body Leu oxidation (Raggio et al., 2006b), Ala and BHBA uptake, and respiratory quotient across the mammary gland. Several of these interactions are probably linked to altered nutrient oxidation. For example, the addition of $\mathrm{C} 3$ to $\mathrm{CN}$ greatly reduced the extra BHBA extracted by the mammary gland compared with $\mathrm{CN}$ alone. Thus, the need to use the ketone body, either to provide energy or as a precursor for lipid synthesis, is reduced markedly when another available energy source is provided. Another example is the observed reduction in whole-body Leu oxidation (Raggio et al., 2006b) when protein and energy supply were both increased, with more of the exogenous AA supplied converted into milk protein and less oxidized to provide ATP. The additional response to $\mathrm{CN}+\mathrm{C} 3$ also means that maximal output of the gland was not achieved with either $\mathrm{CN}$ or C3 alone, so neither provided a complete substitute for the other. This improvement may be linked to the reduction in plasma glucagon when $\mathrm{C} 3$ was added to the CN supply because this hormone stimulates hepatic oxidative metabolism (Veenhuizen et al., 1988). Again, it is unclear whether the glucagon response reduces nutrient catabolism, thus leaving more for anabolic use by the mammary gland, or whether the hormone responds to the lowered surplus after the various removals by the mammary gland.

\section{CONCLUSIONS}

Both C3 and CN treatments increased whole-body glucose Ra, but Ra increase did not solely explain changes in lactose yield because the latter increased only with CN. For both treatments (C3 and CN), separately and in combination, lactose synthesis did not solely depend on glucose uptake. Consideration of the carbon net balance suggested that there was metabolic flexibility in nutrient utilization within the mammary gland, including catabolic and oxidative pathways, to furnish both milk components and the energy to support their synthesis.

\section{ACKNOWLEDGMENTS}

G. Raggio was supported as part of a Marie Curie Training Site grant (MassSchool) from the EU to the Rowett Institute of Nutrition and Health and by the Natural Sciences and Engineering Research Council of Canada. This experiment took place at INRA UMR PL, France. The work on glucose metabolism was 
mainly financed by INRA UMPL. Further financial support came from the core budget of the Rowett Institute of Nutrition and Health provided by the Rural and Environment Research and Analysis Directorate of the Scottish Government. The authors are very grateful to C. Giraudet and Y. Boirie (INRA, LNH, Clermont-Ferrand, France) for the $\left[6,6-{ }^{2} \mathrm{H}_{2}\right]$ glucose enrichment analysis. Our great thanks go to Y. Lebreton (INRA UMR1079 SENAH, Saint Gilles) for assistance with surgical procedures; Y. David, D. Chevrel and the Méjusseaume team (INRA, UMR1080 Production du Lait) for their assistance with the care and feeding of cows; and M. Texier, I. Jicquel, A. Brasseur, S. Marion, L. Finot, S. Letort-Wiart, N. Huchet, M. Vérité, and T. Le Mouel (INRA, UMR1080 Production du Lait) for technical assistance. We are very grateful to Mario Léonard (Agriculture and Agri-Food Canada, Lennoxville, Canada) for IGF-1 analyses. Rabbit anti-hIGF-1, lot\# AFP4892898, was obtained from the National Hormone and Peptide Program (NHPP), National Institute of Diabetes and Digestive and Kidney Diseases, Bethesda, MD, and A. F. Parlow. We gratefully acknowledge National Institute of Child Health and Human Development (NIDDK), and the USDA, as well as the University of Maryland School of Medicine.

\section{REFERENCES}

Annison, E. F., J. L. Linzell, S. Fazakerley, and B. W. Nichols. 1967. The oxidation and utilization of palmitate, stearate, oleate and acetate by the mammary gland of the fed goat in relation to their overall metabolism, and the role of plasma phospholipids and neutral lipids in milk-fat synthesis. Biochem. J. 102:637-647.

Baldwin, R. L., J. France, D. E. Beever, M. Gill, and J. H. M. Thornley. 1987a. Metabolism of the lactating cow. III. Properties of mechanistic models suitable for evaluation of energetic relationships and factors involved in the partition of nutrients. J. Dairy Res. 54:133-145.

Baldwin, R. L., J. France, and M. Gill. 1987b. Metabolism of the lactating cow. I. Animal elements of a mechanistic model. J. Dairy Res. 54:77-105.

Bequette, B. J., F. R. C. Backwell, C. E. Kyle, A. G. Calder, V. Buchan, L. A. Crompton, J. France, and J. C. MacRae. 1999. Vascular sources of phenylalanine, tyrosine, lysine, and methionine for casein synthesis in lactating goats. J. Dairy Sci. 82:362-377.

Bequette, B. J., M. D. Hanigan, A. G. Calder, C. K. Reynolds, G. E. Lobley, and J. C. MacRae. 2000. Amino acid exchange by the mammary gland of lactating goats when histidine limits milk production. J. Dairy Sci. 83:765-775.

Bequette, B. J., N. E. Sunny, S. W. El-kadi, and S. L. Owens. 2006. Application of stable isotope and mass isotopomer distribution analysis to the study of intermediary metabolism of nutrients. J. Anim. Sci. 84(E-Suppl.):E50-E59.

Bickerstaffe, R., E. F. Annison, and J. L. Linzell. 1974. The metabolism of glucose, acetate, lipids and amino acids in lactating dairy cows. J. Agric. Sci. 82:71-85.

Chamberlain, D. G., and J. M. Yeo. 2003. Effects of amino acids on milk production. Pages 367-387 in Amino Acids in Animal Nutrition. 2nd ed. J. P. H. D'Mello, ed. CABI Publishing, Wallingford, UK.

Clark, J. H., H. R. Spires, R. G. Derrig, and M. R. Bennink. 1977. Milk production, nitrogen utilization and glucose synthesis in lactating cows infused postruminally with sodium caseinate and glucose. J. Nutr. 107:631-644.

Couvreur, S., C. Hurtaud, C. Lopez, L. Delaby, and J. L. Peyraud. 2006. The linear relationship between the proportion of fresh grass in the cow diet, milk fatty acid composition, and butter properties. J. Dairy Sci. 89:1956-1969.

Danfaer, A. 1994. Nutrient metabolism and utilization in the liver. Livest. Prod. Sci. 34:115-127.

Gannon, M. C., and F. Q. Nuttal. 1988. The paradoxical response of cardiac glycogen to oral casein hydrolysate in rats. J. Nutr. 118:888-894.

Gannon, M. C., and F. Q. Nuttal. 1995. Physiological doses of oral casein affect hepatic glycogen metabolism in normal food-deprived rats. J. Nutr. 125:1159-1166.

Guinard, J., H. Rulquin, and R. Vérité. 1994. Effect of graded levels of duodenal infusions of casein on mammary uptake in lactating cows. 1. Major nutrients. J. Dairy Sci. 77:2221-2231.

Guinard-Flament, J., E. Delamaire, P. Lamberton, and J. L. Peyraud. 2007. Adaptations of mammary uptake and nutrient use to oncedaily milking and feed restriction in dairy cows. J. Dairy Sci. 90:5062-5072

Hanigan, M. D. 1995. Dynamic models of ruminant mammary metabolism. Pages 370-412 in: Modeling Ruminant Digestion and Metabolism. R. L. Baldwin, ed. Chapman \& Hamm, London, UK.

Hanigan, M. D., and R. L. Baldwin. 1994. A mechanistic model of mammary gland metabolism in the lactating cow. Agric. Syst. 45:369-419.

Hanigan, M. D., J. P. Cant, D. C. Weakley, and J. L. Beckett. 1998a. An evaluation of postabsorptive protein and amino acid metabolism in the lactating dairy cow. J. Dairy Sci. 81:3385-3401.

Hanigan, M. D., L. A. Crompton, J. A. Metcalf, and J. France. 2001. Modelling mammary metabolism in the dairy cow to predict milk constituent yield, with emphasis on amino acid metabolism and milk protein production: Model construction. J. Theor. Biol. 213:223-239.

Hanigan, M. D., J. France, D. Wray-Cahen, D. E. Beever, G. E. Lobley, L. Reutzel, and N. E. Smith. 1998b. Alternative models for analyses of liver and mammary transorgan metabolite extraction data. Br. J. Nutr. 79:63-78.

Heitmann, R. N., and E. N. Bergman. 1980. Integration of amino acid metabolism in sheep: Affect of fasting and acidosis. Am. J. Physiol. 239:E248-E254.

Hurtaud, C., H. Rulquin, and R. Verite. 1993. Effect of infused volatile fatty acids and caseinate on milk composition and coagulation in dairy cows. J. Dairy Sci. 76:3011-3020.

Hurtaud, C., H. Rulquin, and R. Verite. 1998. Effect of level and type of energy source (volatile fatty acids or glucose) on milk yield, composition and coagulating properties in dairy cows. Reprod. Nutr. Dev. 38:315-330.

INRA. 1989. Ruminant Nutrition: Recommended Allowances and Feed Tables. R. Jarrige, ed. John Libbey Eurotext, London, UK.

König, B. A., J. D. Oldham, and D. S. Parker. 1984. The effect of abomasal infusion of casein on acetate, palmitate and glucose kinetics during early lactation. Br. J. Nutr. 52:319-328.

Kristensen, N. B. 2005. Splanchnic metabolism of volatile fatty acids in the dairy cow. Anim. Sci. 80:3-10.

Lemosquet, S., E. Delamaire, H. Lapierre, J. W. Blum, and J. L. Peyraud. 2009. Effects of glucose, propionic acid, and nonEssential amino acids on glucose metabolism and milk yield in Holstein dairy cows. J. Dairy Sci. 92:3244-3257.

Lemosquet, S., G. Raggio, H. Lapierre, J. Guinard-Flament, and H. Rulquin. 2007. Effects of protein supply on whole body glucose rate of appearance and mammary gland metabolism of energy nutrients in ruminants. Pages 581-582 in ISEP - 2nd International Symposium on Energy and Protein Metabolism and Nutrition. Vichy, France. EAAP publication no. 124. Wageningen Academic Publishers, Wageningen, the Netherlands.

Lemosquet, S., S. Rigout, A. Bach, H. Rulquin, and J. W. Blum. 2004. Glucose metabolism in lactating cows in response to isoenergetic 
infusions of propionic acid or duodenal glucose. J. Dairy Sci. $87: 1767-1777$.

Linzell, J. L., and M. Peaker. 1971. Mechanism of milk secretion. Physiol. Rev. 51:564-597.

Madsen, T. G., L. Misciattelli, and M. O. Nielsen. 1999. Effect of amino acid versus propionic acid absorption on the supply and uptake of amino acids and glucose by the mammary gland of dairy cows. Page 82 in the VIIIth International Symposium on Protein Metabolism and Nutrition. Aberdeen, UK. Wageningen Pers, Wageningen, the Netherlands.

NRC. 2001. Nutrient Requirements of Dairy Cattle. 7th rev. ed. Natl. Acad. Sci., Washington, DC.

Palmquist, D. L., C. L. Davis, R. E. Brown, and D. S. Sachan. 1969 Availability and metabolism of various substrates in ruminants. V. Entry rate into the body and incorporation into milk fat of $\mathrm{D}(-)$ $\beta$-hydroxybutyrate. J. Dairy Sci. 52:633-638.

Raggio, G., S. Lemosquet, G. E. Lobley, H. Rulquin, and H. Lapierre. 2006a. Effect of casein and propionate supply on mammary protein metabolism in lactating dairy cows. J. Dairy Sci. 89:4340-4351.

Raggio, G., G. E. Lobley, S. Lemosquet, H. Rulquin, and H. Lapierre. 2006b. Effect of casein and propionate supply on whole body protein metabolism in lactating dairy cows. Can. J. Anim. Sci. $86: 81-89$.

Raggio, G., D. Pacheco, R. Berthiaume, G. E. Lobley, D. Pellerin, G. Allard, P. Dubreuil, and H. Lapierre. 2004. Effect of level of metabolizable protein on splanchnic flux of amino acids in lactating dairy cows. J. Dairy Sci. 87:3461-3472.

Ranawana, S. S. E., and R. C. Kellaway. 1977. Responses to postruminal infusions of glucose and casein in lactating goats. Br. J. Nutr. $37: 395-402$.

Reynolds, C. K. 2006. Production and metabolic effects of site of starch digestion in dairy cattle. Anim. Feed Sci. Technol. 130:78-94.

Rigout, S., C. Hurtaud, S. Lemosquet, A. Bach, and H. Rulquin. 2003. Lactational effect of propionic acid and duodenal glucose in cows. J. Dairy Sci. 86:243-253.

Rigout, S., S. Lemosquet, A. Bach, J. W. Blum, and H. Rulquin. 2002a. Duodenal infusion of glucose decreases milk fat production glucose in grass silage-fed dairy cows. J. Dairy Sci. 85:2541-2550.

Rigout, S., S. Lemosquet, J. E. Van Eys, J. W. Blum, and H. Rulquin. 2002b. Duodenal glucose increases glucose fluxes and lactose synthesis in grass silage-fed dairy cows. J. Dairy Sci. 85:595606.
Roets, E., A. M. Massart-Leën, G. Peeters, and T. Veneman. 1983. Metabolism of leucine by isolated perfused goat udder. J. Dairy Res. 50:413-424.

Rulquin, H., G. Raggio, H. Lapierre, and S. Lemosquet. 2007 Relationship between intestinal supply of essential amino acids and their mammary metabolism in the lactating dairy cow. Pages 587588 in ISEP - 2nd International Symposium on Energy, Protein Metabolism and Nutrition. Vichy, France. Wageningen Academic Publishers, Wageningen, the Netherlands.

SAS Institute. 2004. SAS/STAT 9.1 User's Guide. SAS Institute, Cary, $\mathrm{NC}$.

Siggaard-Andersen, O., P. D. Wimberley, N. Fogh-Andersen, and I. H. Gothgen. 1988. Measured and derived quantities with modern $\mathrm{pH}$ and blood gas equipment: Calculation algorithms with 54 equations. Scand. J. Clin. Lab. Invest. 48(Suppl. 189):7-15.

Smith, G. H., B. Crabtree, and R. Smith. 1983. Energy metabolism in the mammary gland. Pages 121-141 in Biochemistry of Lactation. T. B. Mepham, ed. Elsevier, Amsterdam, the Netherlands.

Van Milgen, J. 2002. Modeling biochemical aspects of energy metabolism in mammals. J. Nutr. 132:3195-3202.

Vanhatalo, A., T. Varvikko, and P. Huhtanen. 2003a. Effects of various glucogenic sources on production and metabolic responses of dairy cows fed grass silage-based diets. J. Dairy Sci. 86:3249-3259.

Vanhatalo, A., T. Varvikko, and P. Huhtanen. 2003b. Effect of casein and glucose on responses of cows fed diets based on restrictively fermented grass silage. J. Dairy Sci. 86:3260-3270.

Veenhuizen, J. J., R. W. Russell, and J. W. Young. 1988. Kinetics of metabolism of glucose, propionate and $\mathrm{CO}_{2}$ in steers as affected by injecting phlorizin and feeding propionate. J. Nutr. 118:13661375

Waghorn, G. C. 1982. Modeling Analyses of Bovine Mammary and Liver Metabolism. PhD thesis. University of California, Davis.

Waghorn, G. C., and R. L. Baldwin. 1984. Model of metabolite flux within mammary gland of the lactating cow. J. Dairy Sci. 67:531544 .

Wieghart, M., R. Slepetis, J. M. Elliot, and D. F. Smith. 1986. Glucose absorption and hepatic gluconeogenesis in dairy cows fed diets varying in forage content. J. Nutr. 116:839-850.

Xiao, C. T., and J. P. Cant. 2005. Relationship between glucose transport and metabolism in isolated bovine mammary epithelial cells. J. Dairy Sci. 88:2794-2804. 